Critical Sociology

\title{
From the Border to the Core: A Thickening Military-Police Assemblage
}

\begin{tabular}{|c|c|}
\hline Journal: & Critical Sociology \\
\hline Manuscript ID & CRS-17-0131.R2 \\
\hline Manuscript Type: & Article \\
\hline Keywords: & $\begin{array}{l}\text { US-Mexico border studies, Critical race theory, War on Terror, War on } \\
\text { Drugs, Military-police assemblage, Militarization }\end{array}$ \\
\hline $\begin{array}{l}\text { Please choose from the } \\
\text { following the areas that best } \\
\text { reflect the general topic of } \\
\text { your submission: : }\end{array}$ & Critical Theory, Race \\
\hline \multirow[t]{2}{*}{$\begin{array}{r}\text { Please choose from the } \\
\text { following geographical areas } \\
\text { that reflect the area of your } \\
\text { study: }\end{array}$} & Western Europe, US and Canada \\
\hline & $\begin{array}{l}\text { Militarization on the U.S.-Mexico border has intensified in America's post- } \\
9 / 11 \text { War on Terror, while America's War on Drugs has escalated } \\
\text { militarization in America's urban core. This infusion of military weapons } \\
\text { and tactics along the border and within America's urban core produces } \\
\text { devastating effects on communities of color. Yet, to date, few critical race } \\
\text { scholars attend to the Wars on Terror and on Drugs as two sides of the } \\
\text { same coin. This paper serves as a bridge between U.S.-Mexico border } \\
\text { studies and critical race studies vis-à-vis a theorization of a thickening } \\
\text { military-police assemblage birthed by the War on Drugs, and intensified by } \\
\text { the War on Terror. To delineate this assemblage, we respond to two key } \\
\text { questions: how and to what degree has the U.S.-Mexico border served as a } \\
\text { staging-ground for US (para)military and surveillance strategies at home } \\
\text { and abroad? And how do discourses on America's urban core compare and } \\
\text { contrast with those on its southern border? We draw upon the cases of } \\
\text { Esequiel Hernández, Jr. and Michael Brown, two teenagers whose lives } \\
\text { were taken by this assemblage, to frame these questions. Our analysis } \\
\text { reveals material, symbolic, and affective links between America's } \\
\text { militarization on the southwest border and within its urban core. }\end{array}$ \\
\hline
\end{tabular}


From the Border to the Core

\begin{abstract}
Militarization on the U.S.-Mexico border has intensified in America's post-9/11 War on Terror, while America's War on Drugs has escalated militarization in America's urban core. This infusion of military weapons and tactics along the border and within America's urban core produces devastating effects on communities of color. Yet, to date, few critical race scholars attend to the Wars on Terror and on Drugs as two sides of the same coin. This paper serves as a bridge between U.S.-Mexico border studies and critical race studies vis-à-vis a theorization of a thickening military-police assemblage birthed by the War on Drugs, and intensified by the War on Terror. To delineate this assemblage, we respond to two key questions: how and to what degree has the U.S.-Mexico border served as a staging-ground for US (para)military and surveillance strategies at home and abroad? And how do discourses on America's urban core compare and contrast with those on its southern border? We draw upon the cases of Esequiel Hernández, Jr. and Michael Brown, two teenagers whose lives were taken by this assemblage, to frame these questions. Our analysis reveals material, symbolic, and affective links between America's militarization on the southwest border and within its urban core.

Keywords

Military-police assemblage, U.S.-Mexico border studies, critical race theory, state, militarization, War on Terror, War on Drugs
\end{abstract}




\section{Introduction}

Just past noon on August 9, 2014, eighteen-year old black student Michael Brown was shot and killed by Darren Wilson, a white police officer, while walking with a friend in the middle of Canfield Drive in Ferguson, Missouri. Wilson fired twelve shots at Michael Brown, striking him at least six times, including two shots to Brown's head (Department of Justice, 2015: 17). Brown, who was unarmed, fell forward in the middle of the street where he lay in a pool of his own blood. Families residing in the nearby Canfield Green, Oakmont, and Northwinds complexes were horrified by the scene of Brown's lifeless body left visible on the street for hours before police covered him.

Seventeen years prior, and nearly 1,200 miles away in Redford, Texas, eighteen-year old Mexican American high school student Esequiel Hernández, Jr. was herding his goats as he did every day. Hernández carried his grandfather's World War I .22 rifle, which he used to fend off wild animals. As Hernández led the goats from the river back toward his home he was shot and killed by U.S. Marine Corporal (Cpl.) Clemente Bañuelos. The fatal shot pummeled Hernández's body into a well. Hernández bled to death on a hill overlooking his home and the local cemetery where he was ultimately buried (Verhovek, 1997).

Despite distance in time and space, the cases of Hernández and Brown bring into focus the relationship between militarization and policing along America's southern border and within its urban core. To date, this relationship remains undertheorized. Critical race scholars have long analyzed the Wars on Drugs and on Terror as distinct racial projects (see Alexander, 2010; Bhattacharyya, 2008; Gamal, 2016; Rios, 2011; Semati, 2010). Yet, few scholars examine their historically and contemporary links. In scanning recent scholarship, we find a gulf between critical race theory and U.S.-Mexico border studies. The former emphasizes formal U.S. jurisprudence while the latter is more open to a cultural-citizenship lens that considers the 
dynamism and contingencies of racial formations and racist practices. We seek to bridge this gap through our theorization of a thickening military-police assemblage-a congealing of military and police praxis brought upon and amplified by America's Wars on Drugs and on Terror. To delineate this thickening military-police assemblage, we respond to two questions: how and to what degree have the U.S.-Mexico border and America's urban core served as a staging ground for U.S. (para)military and surveillance strategies at home and abroad? And how do discourses on America's urban core compare, contrast, and congeal with those on its southern border? To answer these questions we analyze the cases of Esequiel Hernández, Jr. and Michael Brown, alongside a variety of government documents. Our analysis reveals material, symbolic, and affective links between America's militarization along its southwest border and within its urban core. We argue this militarization strips black and brown communities of their political, cultural, and economic self-determination, and ultimately their lives.

We theorize the military-police assemblage as an unstable and dynamic set of discursive, affective, and material properties that, when brought into relationship with one another, produce new articulations of racial power and hegemony (Deleuze and Guatarri, 1987). Our use of articulation refers to the conditions and practices that forge the relationship between racial power, hegemony, and militarization (Hall, 1985). Militarization entails the expansion of enforcement personnel, weaponry, physical barriers, and surveillance technologies to "secure" a spatial territory; it also includes the deployment of phenomenological and affective mechanisms that target intersubjective relations (ways of doing) and formations of subjectivity (ways of being) among those who reside in these territories (AUTHORS, 2015). Our view of militarization is not linear. Rather, we theorize the military-police assemblage as a dynamic, expanding feedback loop that captures and recasts intersubjective relations as targets of its 
power. We conclude our analysis by considering the implications of militarization domestically and internationally for black and brown populations subject to the securing of American Empire (see Hardt and Negri, 2004).

\section{U.S.-Mexico Border Studies and Critical Race Theory}

Our theorizing of a thickening military-police assemblage aims to bridge and advance U.S.Mexico border studies and critical race theory (CRT). U.S.-Mexico border scholars have provided insightful scholarship on immigration and deportation (Golash-Boza, 2012; Massey, 2007), racial profiling, border policing (AUTHORS, 2015; Goldsmith et al., 2009; Romero, 2006) and militarization (Dorsey and Díaz-Barriga, 2015; Dunn, 1996; Rosas 2006). While some studies examine enforcement beyond the interior of the U.S., the majority center Latina/o immigration and citizenship, and the U.S.-Mexico border.

In examining the War on Drugs, Dunn (1996) reveals the military's vision of national security centers gaining operational control of external and internal threats (e.g. insurgents, dissidents, and protests) through Low Intensity Conflict (LIC), a doctrine originally deployed against Third World revolutions. LIC is defined as "a limited politico-military struggle to achieve political, social economic, or psychological objectives. [LIC] is often protracted and ranges from diplomatic, economic, and psycho-social pressures through terrorism and insurgency" (Dunn, 1996: 20). Dunn addresses how LIC emerges from an ongoing collaboration between the U.S. military and Border Patrol in enforcing drug and immigration laws between the 1970s and 1990s. Thus, LIC is instructive for understanding the intensification of militarized practices along the U.S.-Mexico border and the relationship this shares to U.S. imperialism around the globe. 
Elsewhere, Rosas (2006: 336) illustrates how the discursive context of the War on Terror allows for state power to seep into America's core and create a "borderlands condition." This consequently shifts law enforcement's focus from America's frontier to its interior; and recasts black and brown bodies, immigrant and nonimmigrant alike, as exceptions and aberrations to the body politic. Rosas's (2006: 336) "borderlands condition" orients us toward a more comprehensive consideration of how the military-police assemblage articulates itself from the border to the core.

Scaffolding U.S.-Mexico border studies with CRT helps us better understand the differences in manifestations of racial power within the Wars on Drugs and Terror, but also their connections. Early CRT theorizing centered policy and constitutional law within the field of education (Bell, 1980; Delgado and Stefancic, 2001). CRT has since expanded to consider race and racism's operation in a variety of juridico-legal contexts. Gamal (2016) employs CRT to examine how contemporary police militarization constructs some white lives as worthy of protecting while also dehumanizing black lives. In turn, Bracey (2014) offers a theoretical statebased intervention into CRT that dovetails with Omi and Winant's (1994) own racial state theory (RST). RST views the state as inherently racial because it is structured to reproduce a racial hierarchy, and every state action has consequences for the reproduction of racial rule. Racial rule is reproduced through "racial projects" (Omi and Winant, 1994: 56). Racial projects are the building blocks of hegemony, and do the necessary ideological work to reorganize and redistribute the meaning of race and its continued significance in social, political, and economic life. Whereas RST oscillates between an autonomous state that has and acts upon its own interests, and a pluralist model in which the state is "a passive entity available to any sufficiently popular racial project" (Bracey, 2014: 557), CRTS considers the state as an instrument for the 
advancement of whites' interests. CRTS fashions the state as a tool for what Bell (1980: 522) described as "interest convergence"-a way to hegemonize whites' interests as the interests of the state at the expense of other collective interests.

We agree broadly with CRTS, yet we contend that racist state-based action is more nuanced than it allows. Centering the agency of specific elite, white male actors ignores the dynamic conditions of the state that make many more non-elite, nonwhite actors complicit in accomplishing the state's goals. CRTS can benefit from a more robust theorizing of the state's ideological contours, discourses, and practices, including "how 'the state' comes into being ... and what effects this construction has on the operation and diffusion of power throughout society" (Sharma and Gupta, 2006: 8). The state, as Abrams (1988: 58) argues, "comes into being as a structuration within political practice." This structuration is far from stable or uniform, and the rigid binary of oppressor/oppressed is troubled by the fact that it is often those enabling the state's structuration who are also its targets of racial power. The concept of a military-police assemblage helps unmask this duplicitous nature of the racial state and illuminates the material and affective labor involved in the racial state's territorialization. Affective labor describes the work that creates, circulates, and deploys affects that then stick to the U.S.-Mexico border and its residents, structuring how they are then understood by a variety of publics. These affects include "fear," "threat," "terror," and "insecurity." This labor is accomplished by a feedback loop between low-intensity warfare on behalf of Customs and Border Patrol agents, and popular depictions circulated within mass media. Terrorizing imagery of brown-bodied Others circulate through state reports and news media constructing an 'intimate public' where the affective experience of feeling threatened is a condition of belonging to this public (see Berlant, 2008). As jingoism and racism circulate, they necessitate among this intimate public a plan for neutralizing 
them (AUTHORS, 2016). Thus, the military-police assemblage and its territorializing consequences that span America's southern border to its urban core are mutually constitutive.

\section{U.S.-Mexico Border as a (Para)military Stage for White Racial Rule} For nearly two centuries the U.S.-Mexico border has served as a staging ground for racial rule through (para)military logics and tactics. From 1835 to 1918, the Texas Rangers, a paramilitary group colloquially known as los rinches, held a reign of terror by exercising brute force and savage violence against any threats, most notably Native Americans and Mexicans, to the nascent republic (see Paredes, 1958). In times of intense conflict, the Texas Rangers worked in conjunction with the U.S. Army and National Guard. The emergence of the Rangers and their collaboration with other forces signifies a form of governmentality ${ }^{1}$ predicated on the coupling of the military and police that, in consequence, reaffirms white supremacy as a goal of state power.

One of the earliest collaborations between law enforcement and military forces was during the Cortina Wars (1859-1861). After the 1848 Treaty of Guadalupe-Hidalgo, many Mexican landowners were subjected to arbitrary land appropriation tactics by Texas officials, leaving them landless. Juan Nepomuceno Cortina, whose family owned a large land grant near Tamaulipas, Mexico and Brownsville, Texas also fell victim to this massive appropriation of lands. Cortina and his followers, the Cortinistas, were at the center of several raids over land disputes with corrupt Rio Grande Valley officials. On July 13, 1859, Cortina shot a Brownsville Sheriff for mercilessly beating a Mexican elder who had worked for Cortina's family ranch. The

\footnotetext{
${ }^{1}$ Governmentality refers to an art of governing which is an effect of the "techniques and procedures for directing human behavior" (Rose et al., 2006: 83; see also Foucault 2008).
} 
shooting set off armed conflict between Cortina and his men, the Texas Rangers, and the U.S. Army, leaving countless dead and entire communities torched.

The appropriation of land and the political turmoil of the Mexican Revolution (19101920) inspired further uprisings in Mexican communities throughout south Texas. In 1916, the Texas Rangers along with approximately “28,000 federalized National Guard and active-duty Army troops deployed for several months in the Lower Rio Grande Valley" to suppress the uprisings and associated guerilla raids by so-called Mexican sediciosos (Dunn, 1996: 10). This "orgy of bloodshed" led to the deaths of "300 to 5,000 [Mexicans]"; and a little over 120 white civilians and soldiers (Webb 1935: 478; Dunn, 1996: 9). As the revolution continued in Mexico, incursions unfolded on the U.S.-Mexico border. Tensions increased between Mexican Americans and the Texas Rangers as Anglo ranchers employed the Rangers as an extra-legal strong-arm to appropriate land from working-poor Mexican Americans (see Montejano, 1987).

The terrorizing of Mexican communities, appropriation of lands, and massacres on both sides of the border by the Texas Rangers inscribed upon the Mexicano the mark of an "enemy other" that required pacification or eradication. The violent reign of the Rangers contradicted the Posse Comitatus Act (PCA), a law passed after the Civil War (1861-1865) that removed federal troops from the South during reconstruction and banned the military from interfering in domestic matters. Yet, along the U.S.-Mexico border the PCA was ignored, and cooperation between military and law enforcement became the norm for establishing occupation in the region. The role of the Texas Rangers in suppressing indigenous populations deemed a threat to the U.S. highlights the early developmental stages of the military-police assemblage.

Fueled by the Rangers' reign of terror, growing nativist sentiment in the U.S. led to the formation of the Border Patrol in 1924. Many Rangers swapped their state badge for a federal 
one and were absorbed into the ranks of the Border Patrol, taking their racialized suspicions of Mexicans with them (Lytle Hernández, 2010). The formation of the Border Patrol transferred the protection of the 'frontier' to the federal government by way of population control of "undesirables" (e.g. prostitutes, paupers, and Asians), which included Mexicans during times of political and economic turmoil.

In the 1920s, U.S. agribusiness engaged in “imported colonialism” (Ngai, 2004: 129), recruiting Mexican immigrants to work in the fields for paltry wages and subjecting them to inhumane conditions. As visibility of Mexican workers surged, the U.S. enacted increasingly restrictive immigration policies. From “1929-1937, some 458,000 Mexicans were arrested and expelled from the U.S. without due process, including many legal resident aliens and their U.S. citizen children," (Massey, 2007: 16). Massive sweeps by Border Patrol of Mexican immigrants and Mexican Americans reoccurred under the Bracero Program (1942-1964), and then Operation Wetback (1954-1958), resulting in the removal of as many as one million Mexicans and Mexican Americans (Lytle Hernández, 2010). Albeit brief, this history helps illustrate how the birth of the U.S.-Mexico border became unequivocally rooted in the intersections of militarism, policing, and race.

\footnotetext{
America's War on Drugs: Constructing a Military-Police Assemblage In this section, we focus on key historical legislative directives and policies that illustrate the militaristic form of governance along the U.S.-Mexico border from the 1970s to 1990s. This governance encoded this region as "lawless," "dangerous," and in need of security; and proved instrumental in maintaining America's War on Drugs. In his speech to Congress on June 17, 1971, then-President Richard Nixon declared, “America's public enemy number one in the U.S. is drug abuse. In order to fight and defeat this enemy, it is necessary to wage a new, all-out
} 
offensive" (Nixon, 1971). Nixon's statement marks the beginning of America's War on Drugs, a political and military campaign that narrates Latin America as a cartel-driven, drug-smuggling, corrupted region and risk to national security. Nixon's directive laid the groundwork for solidifying the military-police assemblage under subsequent administrations.

The Reagan administration (1980-1988) enacted several policies that radically shifted military governance along the U.S.-Mexico border. An amendment to the PCA via the passage of the Department of Defense's Authorization Act of 1982 gave the military authorization to assist local police in enforcing domestic law (e.g. searches, seizures, and arrests). Chapter 18, entitled “Military Cooperation with Civilian Law Enforcement Officials," section 371-374 allowed for the Army, Navy, Air Force, and Marine Corp to assist with intelligence gathering, provide law enforcement with use of military bases or equipment, and train law enforcement officers. While section 375 notes that the military is not normally given permission to directly participate in interdicting a vessel, search and seizure, or arrests, they could do so if authorized by law (Department of Defense Authorization Act, 1982). In 1986, the National Security Decision Directive 221, or the "Narcotics and National Security" Directive, cast illegal drugs as "an international problem...[which] threatens the national security of the United States," (National Security Decision Directive, 1986: 1). The discursive coupling of drug trafficking with the unauthorized entry of immigrants along the U.S.-Mexico border into an interlocking framework proved instructive for the thickening military-police assemblage. In 1989, then-President Bush signed into law the National Defense Authorization Act, making the military an active force in the War on Drugs. One year later, the National Defense Authorization Act, specifically Section 1208 entitled "Transfer of Excess Personal Property," authorized the temporary transfer of Department of Defense property to local law enforcement agencies for "counter-drug activities." 
Under the Clinton Administration (1992-2000), Section 1208, also known as the 1033 program, was expanded and codified through the 1997 National Defense Authorization Act. It allowed for the transfer of excess personal property to support law enforcement activities, "in counternarcotics and counterterrorism operations, and to enhance officer safety" (National Defense Authorization Act, 1997). The 1033 Act repurposed the transfer of excess military equipment (e.g. facial recognition technology, satellite monitoring, and thermal imaging) to local law enforcement for national security as well as counternarcotics operations. The 1033 Act also discursively coupled narcotics and terrorism, blurring the lines between militarism (external powers) and policing (domestic powers).

Since 1033 became law, America's police forces have become increasingly militarized. The year it was signed into law, the Los Angeles Police Department acquired 600 Army surplus M-16s from the Department of Defense (Los Angeles Times, 1997). From 2008 to 2014, law enforcement agencies acquired an estimated 200,000 ammunition magazines, tens of thousands of machine guns, hundreds of silencers, armored cars, and even aircraft from the Pentagon (Apuzzo, 2014). These transfers are especially egregious given that the base defense budget of the U.S., excluding the primary costs of the wars in Iraq and Afghanistan, grew from \$287 in 2001 to more than $\$ 530$ billion by 2013 (Plumer, 2013).

The tragic irony of these policy shifts is that Esequiel Hernández, Jr. was shot and killed by the U.S. military on his own land. Hernández's death marks the apogee of the tethering of the War on Drugs to the War on Terror as mutually constitutive racial projects. In aggregate these legislative actions produced a thickening military-police assemblage that not only resulted in Hernández's death, but the deaths of countless others along America's southern border and within its urban core. Thus we argue the 2014 death of Michael Brown and resulting violence 
between police and community residents in Ferguson, Missouri is a reverberation of the same military-police assemblage that took the life of Esequiel Hernández in Redford, Texas nearly two decades prior.

\section{Esequiel Hernández, Jr.}

Redford, Texas had approximately one hundred residents in 1997. Few if any were aware that the U.S. Marines had designated their community a drug corridor, deploying secret drug reconnaissance teams dressed in full camouflage and armed with M-16s to watch for smugglers along the Rio Grande River. On the evening of May 20, 1997, Esequiel Hernández, a student at Presidio High School, finished his dinner and began to study his manual for an upcoming driver's license exam. Outside Hernández's village a covert Marine drug reconnaissance mission was underway. Four camouflaged Marines armed with semi-automatic M-16s were moving to an observation post after having remained in hiding during the day. The four Marines were set to be relieved by a new unit at nightfall. At approximately 6 p.m., Cpl. Bañuelos led his unit consisting of Cpl. Roy Torres, Jr., Lance Cpl. Ronald H. Wieler, and Lance Cpl. James Blood to the observation post, despite it being several hours before nightfall. At this time, Esequiel headed outside to herd the family's goats (Katz, 1997).

Esequiel would often take the goats to the banks of the Rio Grande to drink from the river. As Cpl. Bañuelos and his team were headed to the observation post, they spotted Hernández with his goats. Cpl. Bañuelos reported through his radio to his superiors stationed 65 miles away at the Tactical Operations Center in Marfa that "He's armed with a rifle, appears to be, uh, herding some goats or something.” Lance Cpl. James Steen replied back to Bañuelos, "You should remain in your position... and try not to be seen, but you should know what to do," (Katz, 1997). Minutes later, the Marines reported two shots fired by Hernández in their direction 
from nearly two-hundred twenty yards away. After the shots, the now-agitated Marines kept Hernández in their view. A Marine Corp investigation report contends that Hernández could not have known exactly what he was shooting at given the distance. ${ }^{2} \mathrm{Cpl}$. Bañuelos reported via radio to his Command Center, "As soon as he readies that rifle back down range, we are taking him down." Cpl. Steen responded, "Roger, fire back." After the order was given, conflict arose between supervisory personnel on the authorization to fire. Yet, no correction was issued. Shortly after, Cpl. Steen was later replaced as radio operator by Sergeant (Sgt.) Dewbre. Esequiel Hernández began shepherding his goats away from the Marines’ position. However, Cpl. Bañuelos believed Hernández was planning to, "continue around our right flank." The Marines pursued Hernández for twenty minutes, following him to an old fort. There, Hernández led the goats to a ravine and toward a church, narrowing the gap to approximately 140 yards. Cpl. Bañuelos radioed, "I have a visual on the suspect, in front of the church. There's a brown building facing us. He's standing in front of it, he's got the rifle out." Sgt. Dewbre responded “Just give us an update.” Cpl. Bañuelos reported that Hernández, "knows we're out here, he's looking for us." Then, Sgt. Dewbre responded, "You are to follow the ROE [Rules of Engagement]." None of the Marines acknowledged the order.

In the Marine Corp investigation report, Cpl. Bañuelos, Lance Cpl. Blood, and Lance Cpl. Wieler described moving toward Hernández. In his testimony, Cpl. Bañuelos stated Hernández raised his rifle and took aim in the direction of Cpl. James Blood when Bañuelos fired a fatal shot that struck Hernández in the upper right chest (Katz, 1997; United States Marine Corp, 1998). The shot pummeled Esequiel's body into an abandoned water well, leaving only his legs protruding. There, he bled to death just 300 yards from his home. Not a single

\footnotetext{
${ }^{2}$ Quotes and descriptions are taken from the 1998 U.S. Marine Corp Coyne report.
} 
Marine rendered first aid or medical care, though their unit had a trained medic. Initial statements declared that only Bañuelos saw Hernández raise his rifle. Cpl. Wieler later changed his testimony and claimed he saw Hernández raise his rifle (Dunn, 2001). Esequiel Hernández, Sr. was outside chopping firewood when he heard the gunshot. He sensed something was terribly wrong, but never imagined his son had just been shot (Pressley, 1998).

The circumstances surrounding Esequiel Hernández, Jr.'s death remain “fraught with misunderstandings, misperceptions, and gross errors" (MacCormack, 2017). His family, community, church, and even the State of Texas contest the Marine unit's reports. Cpl. Bañuelos and his team admittedly knew very little about Redford, Texas other than being told that it was "not a friendly town," and that most of the residents were in cahoots with "an organized, sophisticated and dangerous enemy" (Katz, 1997). Later, it was publicly exposed that Border Patrol warned the Marines that approximately 75 percent of Redford's population was involved in the drug trade (Dunn, 2001). These falsehoods crystallized an image of a lawless town driven by immoral people. Thus, the affective labor behind the feedback loop between low-intensity warfare and mass media imagery of 'terrorizing racial Others' we described earlier had deadly consequences for young Esequiel.

Esequiel Hernández, Jr. was the first U.S. citizen to be killed on American soil by his own military since the 1970 Kent State massacre (Dunn, 1996; Katz, 1997). Coming at the height of the War on Drugs, his death illustrates the effects of loosening the PCA under the Reagan administration, and opening the floodgates for the military to engage in domestic matters. A West Texas Grand Jury neglected to indict Cpl. Bañuelos in the death of Hernández, rendering the shooting as self-defense, since they believed the young man was a scout for Mexican drug smugglers. Hernández's killing was characterized as a "terrible tragedy, but there was no crime" 
From the Border to the Core

(Katz, 1997), solidifying the state's denial of culpability when deadly force is used against its own citizens.

\section{Michael Brown}

The complete chain of events that transpired on August 9, 2014 lay buried with Michael Brown. Dorian Johnson, Brown's twenty-two year old friend, and Brown were walking single-file along the median of Canfield Drive headed toward Canfield Apartments. Ferguson Police Officer Darren Wilson approached them in his department-issued Chevy Tahoe. In his testimony, Johnson stated that Wilson ordered them to, "Get the fuck on the sidewalk." Johnson protested that he and Brown were, "not but one minute from their destination." ${ }^{3}$ Officer Wilson testified he overheard a radio call about an alleged robbery at the local Ferguson Market where the suspects had stolen cigarillos. Officer Wilson testified that he saw cigarillos in Brown's right hand through his mirror, and that Johnson and Brown fit the description of the dispatched call. Wilson reversed his Tahoe toward Brown and Johnson, parking it at an angle in between the road to stop them from walking any further. Both Johnson and Wilson acknowledged a scuffle unfolded.

Johnson's and Wilson's statements diverge considerably from this point forward. Johnson claims Wilson was verbally and physically aggressive, grabbing Brown by his neck, arm, and shirt, to pull him into the Tahoe. Johnson testified Brown tried to get away from Officer Wilson, but did try to take Wilson's gun. In their struggle, Wilson shot Brown from inside his vehicle. Wilson testified that Michael Brown was the aggressor, attempting to open the driver's side door, then slamming it shut, yelling, "What the fuck are you going to do about it?" Officer

\footnotetext{
${ }^{3}$ Quotes and description of events are taken from State of Missouri vs. Darren Wilson Grand Jury, Volumes IV and V (2014)
} 
Wilson alleged that Brown partially entered the truck window and repeatedly punched Wilson's face.

Officer Wilson admitted to not carrying a taser and testified that he tried to think of how to manage the situation by using his mace, police baton, or flashlight. Wilson maintained that there was no feasible way to get at these three tools, and his only option was his .40 caliber gun. With his gun pointed at Brown, Officer Wilson stated he warned Brown, "Get back or I'm going to shoot you." Wilson contends Brown replied, "You are too much of a pussy to shoot me." Wilson claims that he feared for his life as the two scuffled over possession of Wilson's gun, and that Wilson fired a shot at Brown's right hand, near his thumb. Wilson claims Brown ran away from the police truck, and Wilson pursued Brown. Wilson then claims that, again fearing for his life, he fired a total of twelve shots at the teenager. Four bullets struck Brown's right side, and two bullets struck his head. Medical examiners found one of the wounds to be inconclusive in that they could not ascertain whether it was an entry or re-entry wound (St. Louis County Health, 2014: 4).

In his Grand Jury statements, Wilson describes Brown as “demon”-like and having an, “intense aggressive face." Wilson claims that during their scuffle, he put his hand on Brown's right arm. Echoing $19^{\text {th }}$ and early $20^{\text {th }}$ century racialized narratives of black men's physicality and aggressiveness, Wilson testified, "And when I grabbed him, the only way I can describe it is I felt like a five-year old holding to Hulk Hogan." Eighteen-year old Michael Brown was 6' 4" and weighed approximately 290 lbs. Twenty-eight-year old Wilson was 6'4"' and weighed about 210 lbs. Despite his extensive law enforcement training and his possession of multiple weapons, Wilson claimed he feared for his own life. A St. Louis Grand Jury declined to indict Officer 
Wilson, clearing him of any criminal wrong-doing and rendering Brown's killing a “justifiable homicide."

In the aftermath of Brown's killing, America witnessed a theater of war unfold in Ferguson, complete with the "full weight of the state" (Herreros, 2006: 671). Militarized police personnel armed with AR-15s and armored military vehicles surged the St. Louis suburb. Snipers stood ready with their rifles aimed toward crowds of demonstrators. Tear gas, a chemical agent banned in 1993 by the United Nations in the battlefields of war, was deployed on demonstrators and media personnel. Missouri Governor Jay Nixon summoned over 2000 National Guard members to quell the "lawlessness" and "violence," while Ferguson Mayor James Knowles claimed the National Guard were needed to "maintain order and protect businesses" (Keefe, 2014). FBI documents reveal that the National Guard described the protestors and Ferguson residents as "enemy forces," and “adversaries” (Starr and Bruer, 2015). Mass media amplified these conscriptions through benign repetition and circulation. In this way, the affective labor behind the feedback loop between low-intensity warfare and mass media imagery of 'terrorizing racial Others' during Ferguson's theater of war paralleled that occurring along the U.S.-Mexico border.

Ostensibly the cases of Esequiel Hernández and Michael Brown appear distinct. Upon close examination, however, these cases reveal how the congealing of military and police praxis through the Wars on Drugs and on Terror broaden the state's militarized scope. The powers of the military to "eradicate" external threats and the police to "regulate" internal threats become nebulous and undifferentiated in practice (Rosas 2010: 582). The militarization of the police is coterminous with the "police-ization of the military" (Kraska, 2007: 11). The case of Esequiel Hernández illustrates an emergence of a police-state whose ideological contours embrace a 
militarized approach to controlling society. Meanwhile, the case of Michael Brown illustrates its merging with a national security state, signifying both a tethering and solidification between militarism (i.e. values, beliefs, and assumptions that stress force and violence) and militarization (the actual implementation of these ideological frameworks) against populations deemed threatening (Kraska, 2007: 3). Hence, law enforcement's expanding paramilitary powers helps justify the killing of "threatening" subjects through a national narration of security and terrorism, while simultaneously shielding itself from legal recourse. Communities become "war zones" complete with "enemy combatants" that require suppression through military-grade munitions and technologies.

As racial projects, the Wars on Drugs and Terror amplify and reinforce one another, producing a military-police assemblage that can be hailed both in domestic and global security measures. Five months after the Ferguson protests, New York Police Commissioner William J. Bratton discursively enfolded Ferguson protestors with terrorists when discussing his creation of a Strategic Response Group (SRG): "SRG will put nearly 600 specially assigned officers in locations around the city, and dedicate them to advanced disorder control and counterterror. It is designed for dealing with events like our recent protests, or incidents like Mumbai or what just happened in Paris" (Cusenza, 2015). In one stroke, Bratton blurs the line between civil disobedience and terrorist activity; and free speech with mass murder. Protestors, immigrants, and entire communities are recast as enemies of the state. By reconfiguring these groups as adversarial, or potentially adversarial, the military-police assemblage creates the contours of its own actions. As millions of Americans watched live television coverage of snipers, tear gas, nightsticks and police cuffs being deployed against civilians many asked, "Is there a war happening in Ferguson?" Our analysis shows the war has been here all along. 


\section{Theorizing a Thickening Military-Police Assemblage}

For the past four decades America's racial landscape has been primarily shaped by two policy initiatives: the War on Drugs and the War on Terror. As racial projects (Omi and Winant, 1994), the Wars on Drugs and on Terror constitute a nexus between ideology and practice. The call forth the tethering of a police-state with a security-state that seeks to manage "enemies" from without and within through similar means. The 1033 program's inclusion of counter-terrorism activities helped constitute a security-state that politically and socially marked the bodies of black and brown men and women as "terrorists" and "threats" to the security of the U.S. homeland, and therefore fit for (extra-legal) detainment or deportation. This nexus subsequently determines the content of racial categories, like black and Latino, and rearticulates the meanings attached to each. For example, youths like Esequiel Hernández are recast as "illegal drug runners," while southern border spaces like Redford, Texas are refashioned as sites where drugs, immigrants, and terror coalesce. Similarly, youths like Michael Brown are recast as "violent drug dealers," while urban black spaces like Ferguson and St. Louis are reframed as sites where uncontrollable violence and black pathology run afoul. Black and Latino youths subsequently become vilified as internal and external racialized threats to the racial order. Meanwhile, the southern border of the U.S. and its urban core are reconfigured as in need of federal and state hyper-surveillance for managing these threats from without and within.

The Wars on Drugs and on Terror have terrorizing and territorializing effects on the black and Latino communities they target. Both symbolically and materially inscribe onto black and brown bodies, and the spaces they inhabit, affective dispositions of threat, fear, and insecurity (AUTHORS, 2015). In previous work, we described the U.S.-Mexico border as a space where "phenomenologies of racial power" are encoded and enacted through the localized practice of law enforcement (AUTHORS, 2015: 244). Therein, Black and brown youth become visible 
targets for near-daily harassment by local, state, and federal law enforcement. They are routinely denied due process, and are subject to the most extreme forms of state-sanctioned violence including forced removals and, in the most egregious cases like those of Brown and Hernández, death. Meanwhile, the communities in which black and brown youth are most heavily concentrated become territorialized as both cause and consequence of America's worst social problems; therefore, the spaces most in need of direct surveillance and social control by the state. In turn, this leads to a the crystallization of an intimate public willing to sacrifice these spaces, and the legal, political, and human rights of the people who inhabit them, under the guise of maintaining safety and security. The management of this surveillance and social control is increasingly determined through militarized practices.

Historically, these practices were tested and modified along the U.S.-Mexico border and then imported into America's urban cores. Today, the military-police assemblage re-routes the flow of munitions, personnel, strategy, and discourse in a constant feedback loop between the border and the core. This results in a heightened security state in which threats are always everywhere that there are black and brown bodies, so communities of color require constant surveillance. After the civil unrest in Ferguson, Missouri, former President Barack Obama curtailed the 1033 program. However, in 2017, newly elected President Donald J. Trump quickly reinstated the program and the Department of Justice (DOJ) has promised to restore the open flow of military equipment to law enforcement departments.

The human rights consequences of this thickening assemblage are dire for people of color. The U.S.-Mexico border, cast as a living nightmare, is continually reproduced within the American imaginary-as a porous space riddled with racial Others and in need of immediate pacification and control. Over time, the "military knowledges, tactics, and weaponry," (Rosas, 
2010: 582) deployed on the southern border have been imported into America's urban core where similar fears of racial Others abound. This thickening military-police assemblage legitimizes the state's presence in communities of color, and its claims over black and brown bodies. The state contends these spaces require constant surveillance, and justifies its "kill on site/sight" logics by juridical-ethical means (Ferreira da Silva, 2014: 121). This was evidenced in Officer Wilson's Grand Jury testimony when he declared that the Canfield Green Apartments: [Is] an antipolice area for sure... There's a lot of gangs that reside or associate with that area. There is a lot of violence in that area, there's a lot of gang activity, drug activity, it is just not a very well-liked community. That community doesn't like the police (State of Missouri v. Darren Wilson, Grand Jury Volume V, 2014: 238).

Geographic spaces and the people who inhabit them are deemed always already-threatening, enabling a military-police assemblage to neutralize racialized targets without any questions of its methods. In his interview with ABC News' George Stephanopoulos, Officer Wilson plainly states, "I just did my job” (Berman, 2014).

State-based narratives of Esequiel Hernández and Michael Brown lead us only to their lifeless bodies with little explanation. The state's racial discourse turns their lifeless bodies into fragments, some of which are reinvented and their humanity erased to fit the state's narrative of what occurred. Buried below lay these truths: Esequiel had dreams of passing his driver's test before he was killed. Ironically, he wished to join the Marines after high school. He often discussed how he could use his goats for entrepreneurial purposes. Meanwhile, Michael was enrolled for classes at Vatterott College. He had dreams of becoming a heating and cooling engineer and of one day owning his own air conditioning business. Once uncovered, these truths 
haunt our present racial landscapes and expose how the terror of state-sanctioned violence continues to re-write itself across space and time. As Christina Sharpe (2016: 9) reminds us, "The past that is not past, reappears, always, to rupture the present."

Complicating this 'thickening' is that, rather than Clausewitz's famous quip that war is the continuation of politics by other means, the global stage demonstrates war is becoming the principle organizer of society. As political theorists Michael Hardt and Antonio Negri (2004: 13) state, "War, in other words, becomes the general matrix for all relations of power and techniques of domination." This reformulation of war as the principal organizer of society renders obsolete the differences between "inside" and "outside," between homeland security and foreign intervention. Unlike traditional warfare against nation-states, a war against terror has no temporal or spatial dimensions to it. A war whose purpose is to maintain social order, "must involve the continuous, uninterrupted exercise of power and violence" (Hardt and Negri, 2004: 14). This continuous exercise of power renders spatial distinctions between the U.S.-Mexico border and America's urban core meaningless; and distinctions between America's borders and its imperial reach empty. Simultaneously, this continuous exercise of power conscripts race and outsider status upon the bodies of black and brown bodies in new ways by making those bodies the targets of the state's uninterrupted power. In this way, the thickening military-police assemblage constitutes the very subjects it seeks to control.

\section{Conclusion}

Exploring the contours of the thickening military-police assemblage is a necessary reckoning with the intensification of militarization along the jagged edges of the U.S., and the reverberations within its urban core. The War on Drugs and the War on Terror lay the groundwork for the discursive organization of brown and black bodies and the spaces they 
inhabit as dangerous and threatening. This organization provides justification for the presence and continue thickening of the military-police assemblage. By bridging U.S.-Mexico border studies and CRT with their analyses in militarization and the targeting of communities of color by the state, we enrich our understanding of state power, including its ideological contours (a fear of brown and black communities), discourses (War on Drugs and War on Terror), and practices ("boots on the ground," military weapons, and tactics).

Although we align with a CRT of the state, we aim to push the disciplinary lines by problematizing our understandings of the state, race, and power. As racial projects, the War on Drugs and the War on Terror construct and reproduce what Gamal (2016: 982) describes as a "racial politics of protection" whereby the state selectively reifies the idea that as blacks are targeted and managed, whites experiences security, freedom, and ultimately greater access to state protection. Yet, this rigid binary presents us with problems when examining a space such as the U.S.-Mexico border, where brown agents are policing, detaining, and killing brown bodies. The traditional dichotomy of oppressor/oppressed is complicated when you add lateral forms of violence to conventional vertical hierarchies of power. For us, conceptual boundaries do not always square neatly in the face of the multiplicity of lived experience. Hence, what the state means to communities of color must reckon with how it unveils itself in these spaces.

On a global scale, military-police assemblages are not solely forms of state power witnessed within the confines of a nation-state. Echoing Jones and Johnson (2016: 188), we are skeptical of the idea that as states fortify and militarize their borders, they are taking their, "last gasps of sovereignty." Rather, we view this as a, "re-articulation of sovereign power, not as evidence of its demise" (Jones and Johnson, 2016: 188). America's policing of borders has a global dimension through the use of Border Patrol militarized trainings and what AUTHOR 
(2013: 114) has described as, "sovereignty-work" along other boundaries. Here, the U.S. Border Patrol has trained other police and military forces in Central America (e.g. Guatemala and Honduras), the Middle East (e.g. Afghanistan), Caribbean (e.g. Dominican Republic), and South Africa on how to keep undesirable populations from crossing their borders.

As Miller (2013) notes, "Homeland security no longer stays in the homeland: it's mobile, it's rapid, and it's international." There is a multibillion dollar industry for military contracting companies (e.g. Boeing, Lockheed-Martin, Northrup Grumman, and Elbit) and their investments in border security matters both domestically and abroad. The Racial State is not transnational, but supranational. Its power extends into, and encroaches upon, the political, legal, and military apparatuses of other nation-states, refashioning them and their subjects in the interests of American Empire. Meanwhile, there is evidence of resistance to the military-police assemblage, such as California's Senate Bill 54, an immigrant sanctuary law, against the Trump Administration and its Department of Justice's orders to crack down on crime. Yet, Texas's Senate Bill 4, an anti-sanctuary law, seeks to expand juridico-legal powers by allowing law enforcement to act as proxy immigration officers and question (i.e., racially profile) individuals they suspect of being in the U.S. without documentation. Nevertheless, ruptures and interferences, via local grassroots protests and coalition-building are necessary and possess the potential to undermine state power.

The tragic deaths of Esequiel Hernández and Michael Brown point to a reconfiguration of the decades-long Wars on Drugs and Terror, resulting in a proliferation of military weaponry, frameworks, and collaboration of tactics imported from the U.S. military to local law enforcement. The War on Terror's expansion of military-police powers now overtly allows local law enforcement to manage the threat of racialized bodies by way of military strategies and 
tactics. The importing of military-grade weaponry and artillery into local law enforcement departments across the country has resulted in countless human rights violations and abuses of civil liberties. The actions by $\mathrm{Cpl}$. Bañuelos and Officer Wilson that took the lives of Esequiel Hernández and Michael Brown bring into sharp focus the power of the military-police assemblage to dictate who lives and who dies; and even after death to narrate victims' lives through the lens of this assemblage. As scholar-activists, community leaders, and engaged citizens, we must question, document, and demand transparency and accountability. Our very lives depend on it.

\section{References}

Abrams P (1988) Notes on the difficulty of studying the state (1977). Journal of Historical Sociology, 1(1): 58-89.

Alexander M (2010) The New Jim Crow: Mass Incarceration in the Age of Colorblindness. New York: The New Press.

Apuzzo M (2014) What military gear your local police department bought. The New York Times, 19 August. Available at: https://www.nytimes.com/2014/08/20/upshot/data-on-transferof-military-gear-to-police-departments.html (accessed 18 February 2018).

Bhattacharyya G (2008) Dangerous Brown Men: Exploiting Sex, Violence and Feminism in the War on Terror. New York: Zed Book Ltd.

Bell DA (1980) Brown v. Board of education and the interest-convergence dilemma. Harvard Law Review 93(3): 518-533.

Berlant L (2008) The Female Complaint: The Unfinished Business of Sentimentality in American Culture. Durham: Duke University Press. 
Berman R (2014) Darren Wilson: 'I just did my job'. The Atlantic, 26 November. Available at: https://www.theatlantic.com/politics/archive/2014/11/i-just-did-my-job/383227/ (accessed 1 August 2017).

Bracey G (2014) Toward a critical race theory of state. Critical Sociology 41(3): 553-572.

Cusenza M (2015) Police commissioner Bratton's remarks at the "State of the NYPD". The Forum, 15 February. Available at: http://theforumnewsgroup.com/2015/02/05/strategicinitiatives-community-policing-top-brattons-state-of-the-nypd/ (accessed 26 May 2018).

Deleuze G and Guattari F (1987) A Thousand Plateaus: Capitalism and Schizophrenia. New York: Continuum.

Delgado R and Stefancic S (2001) Critical Race Theory: An Introduction. New York: New York University Press.

Department of Defense Authorization Act (1982) Available at: https://www.congress.gov/bill/97th-congress/senate-bill/815 (accessed 28 September 2017).

Department of Justice (2015) Memorandum report on the shooting of Michael Brown by Ferguson police officer Darren Wilson. Available at: https://www.justice.gov/sites/default/files/opa/pressreleases/attachments/2015/03/04/doj_report_on_shooting_of_michael_brown_1.pdf (accessed 10 October 2017).

Dorsey M and Díaz-Barriga M (2015) The constitution free zone in the United States: Law and life in a state of carcelment. Political and Legal Anthropology Review 38(2): 204-225. Dunn TJ (1996) The Militarization of the U.S.-Mexico Border, 1978-1992: Low-Intensity Conflict Comes Home. Austin: University of Texas Press. 
From the Border to the Core

Dunn TJ (2001) Border militarization via drug and immigration enforcement: Human rights implications. Social Justice 28(2): 7-30.

Ferreira da Silva D (2014) No-bodies: Law, raciality and violence. Meritum-Belo Horizonte 9(1): 119-162.

Gamal F (2016) The racial politics of protection: A critical race examination of police militarization. California Law Review 104(1): 979-1008.

Golash-Boza T (2012) Immigration Nation: Raids, Detentions, and Deportations in Post 9/11 America. New York: Taylor \& Francis.

Goldsmith PR, Romero M Rubio-Goldsmith R Escobedo M and Khoury L (2009) Ethno-racial profiling and state violence in a southwest barrio. Aztlán: A Journal of Chicano Studies 34(1): 93-123.

Hall S (1985) Signification, representation, ideology: Althusser and the post-structuralist debates. Critical Studies in Mass Communication 2 (2): 91-114.

Hardt M and Negri A (2004) Multitude. New York: Penguin Books.

Herreros F (2006) 'The full weight of the state': The logic of random state-sanctioned violence. Journal of Peace Research 43(6): 671-689.

Jones R and Johnson C (2016) Border militarization and the re-articulation of sovereignty. Transactions of the Institute of British Geographers 41(2): 187-200.

Katz J (1997) Marine is cleared in the Texas border death.” Los Angeles Times, 15 August. Available at: http://articles.latimes.com/1997/aug/15/news/mn-22691 (accessed 20 December 2016). 
Keefe B (2014) Ferguson: Where was the national guard? USA Today, 5 December. Available at: https://www.usatoday.com/story/news/nation/2014/12/05/ferguson-where-was-thenational-guard/19936343/ (accessed 1 August 2017).

Kraska PB (2007) Militarization and policing - Its relevance to $21^{\text {st }}$ century police. Police $1(4)$ : 1-13.

Lytle Hernández K (2010) Migra! A History of the U.S. Border Patrol. Berkeley: University of California Press.

MacCormack J (2017) Border killing 20 years ago changed military tactics. San Antonio Express-News, 16 May. Available at: https://www.expressnews.com/news/local/article/Border-killing-20-years-ago-changedmilitary-11142713.php (accessed 18 February 2018).

Massey DS (2007) Understanding America's immigration “crisis.” American Philosophical Society 151(3): 309-327.

Miller T (2013) How the US militarized the Haiti-Dominican Republic border. Mother Jones, 19 November. Available at: https://www.motherjones.com/politics/2013/11/border-patrol-

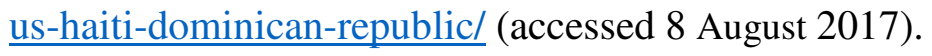

Montejano D (1987) Anglos and Mexicans in the Making of Texas, 1836-1986. Austin: University of Texas Press.

National Defense Authorization Act (1997) National defense authorization act of fiscal year 1997. Available at: https://www.congress.gov/104/plaws/publ201/PLAW104publ201.pdf (accessed 28 September 2017). 
National Security Decision Directive (1986) Narcotics and national security. Available at: https://reaganlibrary.archives.gov/archives/reference/NSDDs.html\#.Wc1m39FOk2w (accessed 28 September 2017).

Ngai M (2004) Impossible Subjects: Illegal Aliens and the Making of Modern America. New Jersey: Princeton University Press.

Nixon R (1971) From the archives: President Nixon on nation's drug problem. Available at: https://www.nixonfoundation.org/2016/06/26404/ (accessed 28 September 2017).

Omi M and Winant H (1994) Racial Formation in the United States: From the 1960s to the 1990s. New York: Routledge.

Paredes A (1958) With His Pistol in His Hand. Austin: University of Texas Press.

Plumer B (2013) America's staggering defense budget, in charts. Washington Post, 7 January. Available at: https://www.washingtonpost.com/news/wonk/wp/2013/01/07/everythingchuck-hagel-needs-to-know-about-the-defense-budget-incharts/?utm_term $=.87 \mathrm{c} 3 \mathrm{a} 4458437$ (accessed 28 September 2017).

Pressley SA (1998) Year later, Marine killing of goatherd remains in dispute. The Washington Post, 14 June. Available at: https://www.washingtonpost.com/archive/politics/1998/06/14/year-later-marine-killingof-goatherd-remains-in-dispute/40a912cb-9d35-46b4-94d9$\underline{492424 \mathrm{c} 185 \mathrm{~d} 4 / \text { ? utm_term }=.00464661 \mathrm{~b} 603}$ (accessed 20 December 2016).

Romero M (2006) Racial profiling and immigration law enforcement: Rounding up of usual suspects in the Latino community. Critical Sociology 32(2-3): 447-473.

Rios VM (2011) Punished: Policing the Lives of Black and Latino Boys. New York: New York University Press. 
Rosas G (2006) The thickening borderlands: Diffused exceptionality and 'immigrant' social struggles during the war on terror. Cultural Dynamics 18(3): 335-349.

Rosas G (2010) Introduction to the new frontiers of race: Culture, criminalities, and policing in the global era, volume 1. Identities: Global Studies in Culture and Power 17(1): 581-585.

Semati M (2010) Islamophobia, culture and race in the age of empire. Cultural Studies 24(2): 256-275.

Sharma A and Gupta A (2006) The Anthropology of the State: A Reader. Malden: Blackwell Publishers.

Sharpe C (2016) In the Wake: On Blackness and Being. Durham: Duke University Press.

St. Louis County Health (2014) Narrative report of investigation. Office of the Medical Examiner. Available at: https://bloximages.newyork1.vip.townnews.com/stltoday.com/content/tncms/assets/v3/ed itorial/c/e0/ce018d0c-5998-11e4-b700-001a4bcf6878/5447202ea9b4e.pdf.pdf (accessed 18 February 2018).

Starr B and Bruer W (2015) Missouri national guard's term for Ferguson protesters: 'Enemy forces'. CNN, 17 April. Available at: http://www.cnn.com/2015/04/17/politics/missourinational-guard-ferguson-protesters/ (accessed 17 August 2017).

State of Missouri vs. Darren Wilson Grand Jury Volume IV (2014) Case: Grand jury-Ferguson police shooting. Available at: https://www.documentcloud.org/documents/1370517grand-jury-volume-4.html (accessed 28 September 2017).

State of Missouri v. Darren Wilson Grand Jury Volume V (2014) Available at: https://www.documentcloud.org/documents/1371222-wilsontestimony.html\#document/p31 (accessed 28 September 2017). 
From the Border to the Core

United States Marine Corp (1998) Coyne report: Investigation to inquire into the circumstances surrounding the Joint Task Force-6 (JTF-6) shooting incident that occurred on 20 MAY 1997 near the border between the United States and Mexico.

Verhovek SH (1997) After marine on patrol kills a teenager, a Texas border village wonders why. The New York Times, 29 June. Available at: http://www.nytimes.com/1997/06/29/us/after-marine-on-patrol-kills-a-teen-ager-a-texasborder-village-wonders-why.html (accessed 16 October 2016).

Webb WP (1935) The Texas Rangers: A Century of Frontier Defense. Austin: University of Texas Press.

Wilson praises LAPD acquisition of 600 Army surplus assault rifles. (1997) Los Angeles Times, 17 September. Available at: http://articles.latimes.com/1997/sep/17/news/mn-33206 (accessed 2 February 2018). 